ISSN : 2550-0198

\title{
PENYULUHAN MEDIA LITERASI: PERAN GURU TAMAN KANAK-KANAK (TK) MENGHADAPI PENGARUH NEGATIF TELEVISI TERHADAP ANAK
}

\author{
Asrinda Amalia*, Aidil Haris \\ Program studi Ilmu Komunikasi, Fakultas Ilmu Komunikasi \\ Universitas Muhammadiyah Riau \\ *Email: asrindamalia@gmail.com
}

\begin{abstract}
Abstrak
Pola menonton TV anak secara umum masih buruk karena konsumsi yang tinggi, bahkan, anak lebih banyak menghabiskan waktu di depan televisi dibandingkan dengan di sekolah. Banyaknya hal negatif dari menonton TV yang bisa mempengaruhi anak tersebut tentunya saja sangat memprihatinkan.Untuk itu peran guru menjadi penting agar televisi tidak berdampak negatif pada anak. Pembentukan karakter anak yang kritis bisa dilakukan apabila guru bisa memberikan pemahaman kepada anak mengenai efek negatif menonton TV sehingga hal-hal negatif bisadihindari. Berdasarkan latar belakang tersebut di atas kami tertarik untuk melakukan tela'ah dengan judul; "Penyuluhan Media Literasi: Peran Guru TK Menghadapi Pengaruh Negatif TV Terhadap Anak”.Tujuan mendasar media literasi adalah mengajar khalayak atau pengguna media untuk menganalisis pesan yang disampaikan oleh media massa, mempertimbangkan tujuan komersil dan politik di balik suatu citra atau pesan media, dan meneliti siapa yang bertanggung jawab atas pesan atau ide yang diimplikasikan oleh pesan atau citra itu. Dari hasil kegiatan penyuluhan mengenai pengaruh negative TV terhadap anak dapat disimpulkan bahwa pengetahuan guru-guru tentang dampak tayangan TV secara umum meningkat meskipun masih ada yang menganggap bahwa acara TV untuk anak-anak tidak berbahaya. Saran yang dapat diberikan adalah masih perlu dilakukan penyuluhan yang lebih intensif untuk lebih meningkatkan kesadaran para guru terhadap pengaruh negative TV.
\end{abstract}

Kata kunci: Literasi, Media, Guru TK

\section{PENDAHULUAN}

Pentingnya pendidikan bagi masyarakatnya sebenarnya telah menjadi salah satu agenda negara sebagaimana dalam Pembukaan Undang-Undang Dasar (UUD) Negera Republik Indonesia tahun 1945 yang menyatakan bahwa salah satu tujuan Negara Republik Indonesia adalah mencerdaskan kehidupan bangsa. Tentunya hal ini bisa terwujud dengan adanya peran serta guru dalam mendidik masyarakat, khususnya anakanak.Guru TK (Taman KanakKanak) terutamanya mempunyai peran penting dalam membentuk karakter anak karena sejak TK nilainilai kehidupan mulai ditanamkan.

Yayasan Pendidikan Media dan Anak menyebutkan, rata-rata anak Indonesia menonton TV selama 3,5-5 jam sehari, itu berarti sama dengan 127, 5-1820 jam per tahun, padahal jam belajar anak sekolah dasar menurut UNESCO harus tidak boleh 


\section{ISSN : 2550-0198}

melebihi 1000 jam per tahun (Sumber: kompasiana.com, diakses 15/05/2017). Hal ini menunjukkan bahwa tingkat ketergantungan anak terhadap TVsangatlah tinggi. Tentunya dengan terpaan tayangan TV yang tinggi tersebut anak akan terpengaruh dengan apa yang dilihatnya di TV. Postman bahkan berkesimpulan bahwa menonton TV tidaklah memperbaiki proses belajar, malah justru cenderung kurang mengembangkan kemampuan berpikir anak dalam tingkat kompleksitas yang tinggi (Postman,2001:159).

Banyaknya hal negatif dari menonton TV yang bisa mempengaruhi anak tersebut tentunya saja sangat memprihatinkan.Untuk itu peran guru menjadi penting agar televisi tidak berdampak negatif pada anak. Pembentukan karakter anak yang kritis bisa dilakukan apabila guru bisa memberikan pemahaman kepada anak mengenai efek negatif menonton TV sehingga hal-hal negatif bisadihindari.

Berdasarkan latar belakang tersebut di atas kami tertarik untuk melakukan kegiatan Pengabdian Masyarakat yang berjudul "Penyuluhan Media Literasi: Peran Guru TK Menghadapi Pengaruh Negatif TV Terhadap Anak".

\section{TINJAUAN PUSTAKA}

\section{Komunikasi Massa}

Komunikasi massa adalah sebuah proses media massa mempengaruhi kehidupan kita sehari-hari melalui pesan-pesan yang berisi informasi tentang cara kita atau orang lain memandang memahami dan membangun realitas dari sebuah dunia nyata. Komunikasi adalah dasar dari kebudayaan kita. Orientasi budaya khalayak banyak sekali mendapatkan pengetahuan tentang budaya baru, bahkan sering kali budaya itu ditanamkan media massa dalam benak khalayak.

Cara pandang seseorang terhadap pesan media massa menentukan pula cara dia dalam menyikapi setiap pesan yang dating kepadanya dan bagaimana dia bersikap. Sering kali ketika disodorkan iklan sabun mandi dengan komitmen yang ditawarkan akan menjadi menarik, terlihat putih cantik, disukai banyak orang. Namun ternyata realitas yang ditampilkan iklan tidak seindah dengan kenyataan yang terjadi pada diri seseorang. Demikian pula sering kita menyaksikan tayangan sinetron atau film yang menampilkan pemeran protagonis yang digambarkan rupawan, pintar dan baik hati sedangkan pemeran antagonis digambarkan buruk rupa, bodoh, jahat, dan sebagainya, namun dalam realitas sehari-hari sering kita menemukan para koruptor justru memilki penampilan yang menarik, terpelajar dan sebagainya.

\section{Literasi Media \& Tujuannya}

Literasi media berasal dari bahasa inggris yaitu media literacy, terdiri dari dua suku kata media berarti media tempat pertukapan pesan dan literacy berarti melek, kemudian dikenal dalam istilah Literasi Media. Dalam hal ini literasi media merujuk kemampuan khalayak yang melek terhadap media dan pesan media massa dalam konteks komunikasi massa. 
Dari defenisi yang dikemukakan baik oleh para pakar komunikasi dan lembaga penggiat literasi media, dapat ditarik kesimpulan bahwa dalm kurun waktu yang lama literasi media yang terbatas hanya pada kajian studi di perguruan tinggi kini sudah bergerak lebih maju lebih terorganisir/terlembaga dan generasi selanjutnya dalam menyentuh pada upayah mempersiapkan kemampuan literasi media setiap individu di masa yang akan dating.

Jelas bahwa literasi media atau melek media bukanlah pengetahuan atau pendidikan tentang media semata, tetapi bergerak lebih jauh lagi yaitu melihat pengaruh buruk yang dapat ditimbulkan dari pesan-pesan media dan belajar mengantisipasinya.

Tujuan mendasar media literasi adala mengajar khalayak atau pengguna media untuk menganalisis pesan yang disampaikan oleh media massa, mempertimbangkan tujuan komersil dan politik di balik suatu citra atau pesan media, dan meneliti siapa yang bertanggung jawab atas pesan atau ide yang diimplikasikan oleh pesan atau citra itu.

\section{Perkembangan Literasi Media}

Literasi media mulai dikembangkan di inggris sekitar tahun 1930-an. Pada sekitar tahun 1960-an, ada suatu perubahan paradigma dalam pendidikan literasi media yang lebih menekankan bekerja dalam masyarakat denga khalayak yang memiliki karakterristik popular culture (budaya pop) ketimbang meyakinkan secara frontal bahwah budaya pop itu merusak.Oleh karea pada masa itu budaya pop merupakan arus utama kebudayaan.

Sejak tahun 1970-an di Inggris muncul kursus-kursus pertama secara formal dalam focus studi dalam dunia film kemudian selanjutnya muncullah studi media sebagai opsi untuk kelompok muda didalam cakupan usia 14-19 tahun. Di inggris sendiri dalam kurikulum pendidikan sejak tahun 1990 mengahusrkan persyaratan untuk mengajar sekitar media sebagai bagian dari bahasa inggris.Negara inggris juga dikenal sebagai pionirdari pengembangan pendidikan untuk melek media di dunia.

Perkembangan literasi media di Australia, pendidikan media dipengaruhi oleh pengembanganpengembangan di inggris berhubungan dengan inokulasi dan seni-seni populer yang ada.Salah seorang pakar pendidikan media di Australiayakni Graeme Turner dan Yohanes Hartley yang membantu mengembangkan Australia Media Education., suatu studi dan kajian mengenai media.

Perkembangan literasi media di Negara Afrika Selatan, tuntutan akan pendidikan media meningkat sebagai akibat penghapusan politik Apartheid dan adanya pemilihan yang demokratis tahun 1994. Konferensi nasional yang pertama dari media education di afrika selatan dilaksanakan tahun 1990 dan baru menjadi kurikulum nasional secara tertulis pada tahun 1997.Karena kurikulum ini bekerja keras untuk mencerminkan nilai-nilai dan prinsipprinsip daari suatu masyarakat yang domokratis. 
ISSN : 2550-0198

Perkembangan literasi media di Negara-negara Eropa dalam beragam bentuk. Pendidikan media mulai di perkenalkan dalam kurikulum pelajaran sekolah dasar di Finlandia tahun 1970 dan di sekolah menengah atas tahu 1977, namun bru serentak dilakukan pada sekitar tahun 1990-an.

Perkembangan literasi media di Indonesia merupakan proses untuk mencari formula bentuk yang sesuai, hal ini terjadi karena keterlambatan masuknya literasi media di Indonesia disaat Negara-negara maju sudah berkembang aktivitas literasi media meraka.

\section{METODE PELAKSANAAN}

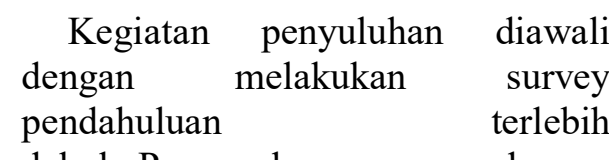
dahulu.Pengenalan program dengan guru-guru TK Amil Hasanah Hasil survey yang dilakukan menunjukkan bahwa penyuluhan media literasi mengenai penontonan TV belum pernah dilakukan dan masih banyak diantara guru-guru tersebut kurang memiliki kesadaran mengenai dampak negative tayanganTV. Penyuluhan media literasi dilakukan dengan metode ceramah dan tanya jawab. Ceramah dilakukan untuk menyampaikan informasi TV menyajikan berbagai macam program tayangan yang berdasar realitas, rekaan dan ciptaan dalam berbagai bentuk seperti berita, pendidikan, hiburan dan iklan.Secara teknis TV memiliki kemampuan mencapai khalayak dalam jumlah tak terhingga pada waktu bersamaan. Disamping itu juga, disampaikan mengenai fakta negative TV di Indonesia.

\section{PEMBAHASAN}

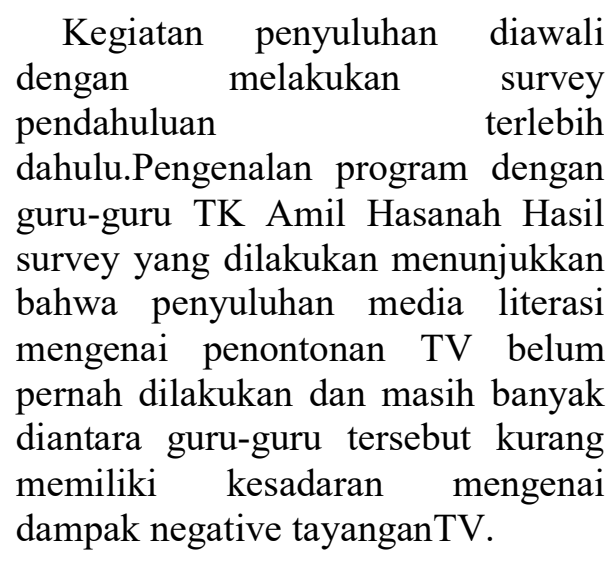

Penyuluhan media literasi dilakukan dengan metode ceramah dan tanya jawab. Ceramah dilakukan untuk menyampaikan informasi TV menyajikan berbagai macam program tayangan yang berdasar realitas, rekaan dan ciptaan dalam berbagai bentuk seperti berita, pendidikan, hiburan dan iklan.Secara teknis TV memiliki kemampuan mencapai khalayak dalam jumlah tak terhingga pada waktu bersamaan. Disamping itu juga, disampaikan mengenai fakta negative TV di Indonesia, diantaranya:

- Tahun 2002 jam tonton televisi anak-anak 30-35 jam/hari atau $1.560-1.820 \mathrm{jam} / \mathrm{tahun}$, sedangkan jam belajar SD umumnya kurang dari1.000jam/tahun.

- $85 \%$ acara televisi tidak aman untuk anak, karena banyak mengandung adegan kekerasan, seks dan mistis yang berlebihan danterbuka.

- Saat ini ada 800 judul acara anak, dengan 300 kali tayang selama $170 \mathrm{jam} / \mathrm{minggu}$ padahal satu minggu hanya ada 24 jam X 7 hari $=168 \mathrm{jam}$.

- $40 \%$ waktu tayang TV diisi iklan yang jumlahnya $\quad 1.200$ 
ISSN : 2550-0198

iklan/minggu, jauh diatas ratarata dunia 561iklan/minggu.

Fakta-fakta negative tersebut akhirnya dapat mengakibatkan dampak negative apabila anak menonton TV secara berlebihan. Dampak negative pada anak usia 0-4 tahun: penontonan kemampuan herbal membaca maupun maupun memahaminya, menghambat anak dalam mengekspresikan pikiran melalui tulisan. Sedangakan dampak negative pada anak usia 5-10 tahun: dapat meningkatkan agresivitas dan tindak kekerasan, tidak mampu membedakan antara realitas dan khayalan. Selain itu, penontonan TV yang berlebihan dapat membuat anak berprilaku konsumtif karena rayuan iklan, mengurangi kreatifitas anak karena kurang bermain dan bersosialisasi sehingga menjadi manusia individualis, merenggangkan hubungan antar anggota keluarga karena waktu berkumpul dan bercengkrama dengan anggota keluarga tergantikan dengan nonton TV, serta anak dapat matang secara seksual karena sering melihat adegan seksual dalam tayanganTV.

Selanjutnya, setelah ceramah dilakukan tanya jawab untuk memperdalam pengetahuan dan meningkatkan kesadaran guru-guru terhadap pengaruh negative TV. Tanya jawab berlangsung cukup menarik karena banyak guru-guru yang antusias terhadap media literasi.Mereka menjadi lebih terbuka dan sadar bahwa tayangan TV, bahkan tayangan anak-anak, memiliki pengaruh negative. Berikut faktor pendukung dan penghambat yang ditemui di lapangan;
1. Faktor Pendukung:

- Akhir-akhir ini tayangan TV mendominasi kegiatan kesehariananak-anak.

- Keingintahuan dari peserta penyuluhan yang cukup besar terhadap materi yang diberikan.

- Antusiasme dan partisipasi aktif dari guru-guru dalam mengikuti penyuluhan medialiterasi

2. Faktor Penghambat:

- Beberapa guru masih menganggap bahwa acara TV untuk anak-anak tidak begitu berbahaya.

- Masih diperlukan informasi dan penyuluhan media literasi yang berkelanjutan untuk lebih meningkatkan kesadaran para gurutersebut.

\section{KESIMPULAN}

Dari hasil kegiatan penyuluhan mengenai pengaruh negatiF $\mathrm{TV}$ terhadap anak dapat disimpulkan bahwa pengetahuan guru-guru tentang dampak tayangan TV secara umum meningkat meskipun masih ada yang menganggap bahwa acara TV untuk anak-anak tidak berbahaya.

\section{UCAPAN TERIMAKASIH}

Dalam perencanaan, pelaksanaan pengabdian ini, hingga penulisan laporan ini penulis banyak menerima bantuan dari berbagai pihak. Untuk itu ijinkan kami untuk menyampaikan ucapan terimakasih kepada: 
ISSN : 2550-0198

1. Lembaga Penelitian dan Pengabdian Kepada Masyarakat (LP2M) UMRI yang telah memberi kesempatan dan bantuan terhadap pengabdian ini.

2. Dekan Fakultas Ilmu Komunikasi Umri yang telah memberikan dukungan terhadap pengabdian penyuluhan ini.

3. Guru-Guru TK Amil Hasanah Pekanbaru yang telah ikut sebagai peserta penyuluhan ini.

4. Semua pihak yang tidak dapat tim pengabdian sebutkan satu persatu yang telah banyak membantu terselenggaranya pengabdian masyarakat ini.

Semoga Allah SWT melimpahkan pahala pada jasa-jasa semuanya. Aamiin.

\section{DAFTAR PUSTAKA}

[1] AAP. 2001. Media Violence. PEDIATRICS Vol. 108 No. 5 November 2001, pp. 12221226. Wirodono, Sunardian. 2005. Matikan TV-MU. Yogyakarta : Resist Book

[2] Jalaluddin Rakhmat, Psikologi Komunikasi, Bandung: Remaja Rosda Karya, 2008.

[3] Singgih D. Gunarso dan Y Singgih D Gunarso, Psikologi untuk Membimbing, Jakarta: Gunung Mulia, 2007.

[4] Postman, Neil. 1995. Menqhibur diri sampai mati: Mewaspadai Media Televisi. Jakarta: Pustaka Sinar Harapan
[5] Pangkapi, Eko, 2011. Televisi dan Anak, media.kompasiana.com, diakses 12 November 2011

[6] Redaksi, 2001, Bahaya Menonton Televisi bagi Anak, tempointeraktif.com, diakses 15 Mei 2017

[7] Redaksi, 2010, Pola Menonton Televisi Anak Sangat Buruk, health.kompas.com diakses 15 Mei 2017

[8] Kidia, 2011. Pengaruh Nonton TV pada Anak-anak, kidia.org, diakses 15 Mei 2017 